\title{
WANG DA-HONG'S PROJECT "SELENE MONUMENT TO MAN'S CONQUEST OF THE MOON" IN THE CHINESE CULTURAL RENAISSANCE MOVEMENT
}

\author{
中国文化復興運動における王大閏の「人類登月記念碑」案について \\ Sheng Chieh KO* and Takahiro TAJI** \\ 郭 聖 傑, 田路 貴 浩
}

\begin{abstract}
Taiwanese architect Wang Da-Hong designed and promoted the Selene Monument project during the 1960s and 1970s. The monument was to commemorate the first lunar landing achieved by the US Apollo 11 mission in 1969. Wang wanted the monument not only to celebrate the achievements of American science and technology, but also to pay tribute to the spirit of Chinese culture. The project can also be perceived as a way Wang found to search for the essential idea, the Chineseness. This paper will analyze the contents of the Selene project, including its promotion and design, by examining documents and drawings from the Wang Da-Hong collection of the National Taiwan Museum. After an overview of the entire project, it can be said that the Selene project was a highly political and ideological project, but Wang kept a certain distance from any political and ideological discussions during the Cold War era and he stressed the autonomy of architecture by advocating its spiritual values. Also, the Selene project represents the mutual existence of relative matters and reveals the sense of mystique as an essential idea behind Wang's conception of Chineseness.
\end{abstract}

Keywords : Wang Da-Hong, Selene project, Chineseness, Chinese cultural renaissance 王大閏，人類登月記念碑，中国性，中国文化復興運動

\section{Introduction}

\subsection{Background and Purpose}

Taiwanese architect Wang Da-Hong (1917-) published Selene Monument to Man's Conquest to the Moon (the Selene project) in December 1969. The white monument, named after the Greek goddess of the moon, stands on podium and is distinguished by its twin stelae reaching toward the sky. Wang designed it voluntarily in order to commemorate man's first lunar landing achieved by the US Apollo 11 mission in July 1969. Later, it was to become a gift from Taiwan to the United States for the US bicentennial celebration of independence in 1974. However, in the end, the Selene project was never realized.

Wang has claimed that the project was designed in $1965^{1)}$. Wang took his inspiration from a novel he read as a teenager, H.G. Wells' The First Man on the Moon, and since then he had always believed that someday humans would land on the moon.
The 1960s was the busiest period of Wang's career. Not only because of the rapid growth of his business, but also because he had a chance to participate in government projects. The same year that Wang designed the Selene project, he also won the competition for design of the Sun Yet-Sen Memorial Hall (孫文記 念館), one of the most symbolic and important public buildings in Taiwan. Although Wang was very busy during this period of time, he still tried to support the promotion of the Selene project.

Wang is known as an architect who highly valued Chinese culture and devotedly searched for his idea of Chineseness throughout his career. Although the Selene project was designed to commemorate an achievement of the United States, he nonetheless claimed that the monument possessed "significant spirit of the Chinese culture" in $i^{2)}$. We may regard the Selene project as a representative project that embodies Wang's concept of Chineseness, but this viewpoint or even the project itself are
* Research Fellow, Graduate School of Engineering, Kyoto University, M.Eng.

** Assoc. Prof., Graduate School of Engineering, Kyoto University, Dr.Eng.
京都大学大学院工学研究科 研修員・修士 (工学) 京都大学大学院工学研究科 准教授・博士 (工学) 
barely discussed in existing research. This paper will clarify the entire contents of the project, including its promotion and design, through a study of the material acquired from Taiwan National Museum's Wang Da-Hong collections. After providing an overview of the project, Wang's intention and the meaning of Chineseness in this project will be discussed.

\subsection{Thesis review}

There are no known theses that specifically discuss the Selene project, but there are those that focus on Wang's public buildings, especially Sun Yet-Sen Memorial Hall. For instance, the prominent researcher of Taiwan architecture Lee Chian-Lang mentions, "The origin of Sun Yet-Sen Memorial Hall's form might be traced back to Tang or Song dynasty, but Wang brought a new idea...he used the traditional style directly, but drew the outline in a simple style..."3). The specialist of Wang's research Shyu Ming-Song mentions that the influence of Mies van der Rohe can be seen in the memorial hall. In contrast to Mies works which are devoid of symbols, Wang chose to incorporate elements of Chinese tradition in his design of the roof $^{4)}$. As for academic thesis, Chiang Ya-Chun's thesis is representative. She claims that the memorial hall is the best example in the debate between modernism and Chinese tradition, because Wang showed a balance between tradition and modernity $^{5)}$. All of this shows that the high level of focus on Sun Yet-Sen Memorial Hall and its eclectic form. In contrast, the Selene project, with its apparent lack of Chinese symbols, was merely referenced but not discussed at length ${ }^{6)}$. Therefore the entire contents of the Selene project still have not been clarified in the existing literature.

\subsection{Research material}

National Taiwan Museum's Wang Da-Hong collection is the primary source of material for this paper. This collection is a part of "Collecting and researching the drawings of Taiwan classic post-war architecture project" ${ }^{7}$ ) in 2007. All materials are digitalized and a catalog was published on the museum's website. However, the collection is still not available for public access ${ }^{8)}$. With a special permit, the authors obtained the entire digital data of the collection. The data include drawings from 27 projects, over 1137 sheets of material. There are also more than 780 sheets of manuscripts and photos in the collection.

Regarding the Selene project, there are 290 sheets of

Table1 the contents of Selene's collection

\begin{tabular}{|c|c|c|c|}
\hline \multicolumn{3}{|c|}{ Type } & Quantity \\
\hline \multicolumn{3}{|c|}{ Drawings } & 73 \\
\hline \multirow{5}{*}{ Manuscript } & \multirow{3}{*}{$\begin{array}{l}\text { Draft of } \\
\text { proposal }\end{array}$} & Introduction & 10 \\
\hline & & English program & 34 \\
\hline & & Chinese program & 14 \\
\hline & \multicolumn{2}{|c|}{ Letter } & 43 \\
\hline & \multicolumn{2}{|c|}{ Handwritten memo } & 16 \\
\hline \multirow{3}{*}{ Document } & \multicolumn{2}{|c|}{ Official record } & 36 \\
\hline & \multirow{2}{*}{ Publication } & Related to design & 21 \\
\hline & & About Selene & 16 \\
\hline \multicolumn{3}{|c|}{ Others (including photos, maps) } & 27 \\
\hline \multicolumn{3}{|c|}{ Total } & 290 \\
\hline
\end{tabular}

material, including 73 drawings and 190 sheets of written material. There are also 27 sheets of photos, maps, and other material. These materials were all classified by the museum but were not categorized ${ }^{9}$ ). Hence, the authors make all categorizations in this paper. A detailed categorization of the written materials is shown in table 1 ; the details of the drawings will be shown in chapter 5 .

\subsection{Overview of the paper}

Chapter 2 focuses on Wang's public buildings in the 1960s and provides a background study of the project. In chapter 3 , the authors focus on official documents and private letters to analyze and provide a scope of the project's promotion. Chapter 4 attempts to clarify the specifics of the design by examining the programs for the project in the museum's collection. Chapter 5 focuses on the project's design and tries to understand the various revisions using the drawings of the collection. In the final chapter, the intention of the project and Wang's concept of Chineseness will be discussed.

\section{Wang's public building works in the $1960 \mathrm{~s}$}

Wang was born in a Catholic family and has been considered as one of the Kuomintang（国民党，KMT） political party's second-generation celebrities. His father, Wang Chung-Hui ${ }^{10)}$ (王寵惠) played an important role in establishing both the Republic of China (中華民国, ROC) and also the KMT party. For this reason, Wang became a family friend of top KMT leaders, including former First Lady Soong May-Ling (宋美齢). After Wang graduated from GSD ${ }^{11}$ ) in 1943, he joined the Chinese embassy in Washington D.C. Wang also participated in the Great Shanghai Urban Design Project (大上海都市計画, 1945-49) soon after he returned to China in 1947, despite lacking any actual working experience. At the later stages of the Chinese Civil War in 1949, Wang and his family left China and went to Hong Kong; three years later they moved to Taipei under the order of ROC leader Chiang Kai-Shek (蒋介石). The actions Wang's family took showed their stance against the Communist Party of China (中国共產党, CPC).

Public buildings in 1960s Taiwan, especially government facilities, served as a form of propaganda. Beginning in the 1950s, KMT focused on developing Taiwan's cultural buildings. The motivation of KMT was to emphasize the party as the only legal

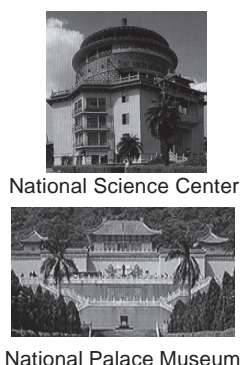

Fig.1 palace style buildings

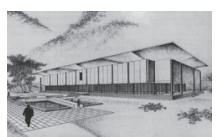

National Palace Museum project

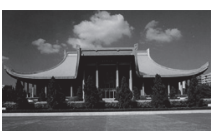

Sun Yet-Sen Memorial Hall Fig.2 public buildings in Wang's works 
regime that could represent China. The KMT initiated the Chinese Cultural Renaissance（中華文化復興運動, 1967-76) to oppose the Great Cultural Revolution (文化大革命) and protect Chinese traditional culture. The cultural movement in Taiwan advocated the value of Chinese culture and greatly influenced the development of fine arts, including architecture. For this reason, buildings like the National Science Center（国立科學 館, 1958, Fig. 1) and the National Palace Museum (故宮博物館, 1966, Fig. 1) presented a style called Palace style, which became the main trend for all public facilities.

Wang submitted designs for four public buildings (Fig. 2) in this period: the National Palace Museum project（故宮博物館計画, 1961), Sun Yet-Sen Memorial Hall (孫文紀念館, 1965-1972), the Ministry of Foreign Affairs building (外交部, 1971), and the Ministry of Education building (教育部, 1971). These buildings were to serve as iconic buildings and in their design Wang was asked to show the representable features of Chinese architecture to the public. However, because Wang insisted on his own design, which was influenced by modernism, his museum project was rejected while the Sun Yet-Sen Memorial Hall design was the result of a compromise that aligned the design more closely with the KMT's cultural policy ${ }^{12)}$. Wang once claimed, "Renaissance is not meant to restore ancient ways. We present new things, not old ones... ${ }^{\text {"13) }}$ Wang showed his intention to find a new solution to represent Chineseness, but under the pressure of KMT, his designs could not break free from the typical images of Chinese architecture. At the same period that Wang negotiated the design of Sun Yet-Sen Memorial Hall with the government, he started to design the Selene project.

\section{The promotion of the Selene project}

In this chapter, the promotion of the Selene project is discussed based on public documents and letters ${ }^{14)}$ taken from the collection.

\subsection{Promotion in the early 1970 s}

Wang started to promote the Selene project at the end of the 1960s. The first action he took was to publish the project in 1969 in the American magazine Progressive Architecture (PA ${ }^{15}$ ). An introduction and a photo of the model were published. A few months later, a Hong Kong magazine Far East Builder ${ }^{16)}$ also published the Selene plan along with photos of the model (Fig.3). In the same year, Wang contacted NASA in order to get the name list of the Apollo 11 staff and also to inform them of the project ${ }^{17)}$.

In 1971, Wang started to ask around for ways to realize the Selene project, and began by contacting the International House of Taipei ${ }^{18)}$. They advised him that the monument should be built first in Taipei and then all over the world ${ }^{19)}$. Also, the construction costs should be covered by gathering donations. Although Wang preferred that Selene be built in Houston ${ }^{20)}$, he accepted the advice and tried to pursue this course of action until his efforts were stalled by the first oil crisis in 1973, when construction limitations were declared in Taiwan ${ }^{21)}$. Wang then turned to his friend Hwang, a local architect in Houston, to ask about the possibility to realize the project together ${ }^{22)}$. Around that time the minister of Foreign Affairs also suggested that the Selene project could be promoted as a national gift to celebrate the bicentennial of American Independence, ${ }^{23)}$ a step that would lead to the establishment of a construction committee.

\subsection{The ROC Citizens to build the Selene Monument to Man's} Conquest of the Moon Committee

The "ROC Citizens to build the Selene Monument to Man's Conquest of the Moon Committee" was established on October $18^{\text {th }} 1974$ in Taipei by the Sino-American Cultural and Economic Association ${ }^{24)}$. Members of the committee were primarily politicians and celebrities, and several members also served on the Chinese Cultural Renaissance committee ${ }^{25)}$. The purpose of the committee was to lobby support for the monument and gather donations. They promoted donations to the project as patriotic behavior ${ }^{26)}$. Wang claimed that he didn't belong to the committee, but was engaged as the design adviser responsible for the design only ${ }^{27)}$.

According to the official schedule ${ }^{28)}$, the preparations for the construction should have been completed before February 1975 and the construction was planned to start at the suburban area of Houston on July $4^{\text {th }} 1976$. However, the schedule was delayed due to several unexpected setbacks. For instance, the proposal for the selection of a site arrived in the beginning of 1975 , just one month before the preparations were to be completed ${ }^{29)}$. Also, it seems the government chose not to support the project actively. In the official record dated March $1975^{30)}$, a congressman in the Legislative Yuan (立法院) asserted that the project should be led by the government rather than a civil organization. He also argued that Selene was unable to express the cultural meaning it proposed. He criticized the form of Selene as "too simple and meaningless" and pointed out several alternative examples of appropriate styles for national monuments, such as the style of the Temple of Heaven (天壇) in Beijing. The congressman's opinions offer a general idea of how a public building was supposed to be envisioned during the Chinese Cultural Renaissance. Wang didn't respond to these opinions directly, but contents about how Selene represented Chinese culture were added in publications from 1975 onward $^{31}$. Wang mentioned the form of Selene represented the Chinese philosophy of Yin-Yang (陰陽) ${ }^{32}$.

Promotion activities were stopped after Chiang Kai-Shek's death in April 1975. With the committee chairman's resignation 
at the end of 1976 and the end of the diplomatic relations between ROC and USA in 1979, the promotion was officially ended. Due to insufficient donations ${ }^{33)}$ and a lack of government support, the promotion of the project did not make progress to the extent that Wang claimed to the public.

Wang continued promoting Selene privately until the 1990s. Instead of advocating the success of the first lunar landing, Wang shifted his focus. In a letter Wang sent to Hwang in $1980^{34)}$, he said, "the Selene monument is a memorial to man's first landing on the moon, dedicated not as much to the achievement of man as to the glorification of his Creator." Wang implied Selene was more like a religious monument. In the following chapter, we can find this intention was not mentioned suddenly in 1980 , but was rather implied as early as the middle of 1974 . In 1988, the Selene project was once again published, this time in the magazine Taiwan Architect. A complete set of drawings was shown, but it failed to garner much attention. In the 1990s, Wang still tried to contact some people who might have the ability to influence the government, such as Soong May-Ling. In these communications Wang also mentioned the religious meaning that Selene represented ${ }^{35)}$. Although Wang made great efforts to promote the Selene project, it was never realized.

\section{4. "The Selene program"}

In the collections, there are pages of materials about the programs of Selene. Although these pages were unbound, they appear to be the English brochure for promotion which Wang entitled "The Selene program." It includes a short introduction and project's programs. In this chapter, these programs are discussed $^{36)}$. Before this examination, the introduction in PA can offer the primary understanding of the project. The project was introduced as composing of twain stelae, which symbolize the arms of man reaching for the moon. Between the stelae, at the bottom, there is a circular hall reached by a stairway of 15 steps from the podium and in the center, there is a memorial block with the names of the 29 Apollo 11 staff. The height of the monument is $252.71 \mathrm{ft}$., which represents the distance in miles between the moon and earth. Inside the monument, there are two reliefs of female and male characters on each side of wall that depict the Chinese myth, The Flight of Chang-O to the Moon (嫦娥奔月) ${ }^{37}$.

The authors collected 13 sets of programs from the collection $^{38)}$. None of them are dated, but they reveal similar content with slight changes between versions that reveal a process of rewriting. Basically, Wang himself categorized the programs into four main sections: "Concept", "Design", "Approach", and "Materials". Concept and Design focus on his ideas about Selene from both an abstract and specific point of view; Approach and Materials mention more details about its design. Furthermore, the authors categorize all content of each section into five versions. Version 1 to 5 reveal a sequence of rewriting, but the differences are limited. The following examination will highlight the differences between these versions.

Concept: In version 1 the concept is explained by stating that "the moon is feminine in almost every language. Hence, a dual representation as opposed to a single unit, such as the Egyptian obelisk or the Greco-roman column, both much used as monuments and both of phallic symbolism." On the other hand, from version 2 to 5 , the concept description declares that "the arm-like stelae raised towards the sky form an obvious symbol of man's age-old dream to reach the moon." Version 1's concept cannot be found in any other versions, but the creation of a "dual representation" can be perceived as the primary intention that inspired Wang to develop the conceptual image of human arms.

Design: The design of the monument is discussed in this subject. Wang explained the design from two parts: the monument and the podium. As for the monument, Wang specifically mentions that he attempted to design arm-like stelae in version 1 . However, in the later versions, this intention was provided in the Concept part of the program. This section also focuses on the interior space. The circular hall is given a diameter of $30 \mathrm{ft}$. and a height of $252.71 \mathrm{ft}$. in every version.

Wang started to use the word "chapel-like" to describe the space of the hall from version 3 to 5 . He specifically pointed out that the chapel-like space was "mystic and religious" in version 4 and 5. In addition, he wrote, "the enclosed space of the hall is at once close and infinite, a symbol of man himself, a mere speck in space, yet boundless in his aspirations." He also pointed out the contrast of vertical and horizontal space of the hall and similar wording is found in every version. This section of the program highlights that the interior space of the Selene project is mystic and religious as the space relates to a specific object inside the hall. There are three symbolic objects inside the hall: the memorial block, the reliefs, and the stained glass metal screen (table 5). The description of the stained glass metal screen states that "these three works of art make up a triptych, lending to the circular hall a mystic and religious ambiance." ${ }^{39)}$ Wang also mentions that the theme is "the Creation." ${ }^{40)}$ This screen is only found in version 4 and 5 , while the memorial block and reliefs are found from version 1 to 5 .

As for the podium, several specific changes can be found. In version 1, the size is changed from $90 \mathrm{ft}^{2}$ to $120 \mathrm{ft}^{2}$. However, Wang didn't mention the size in any later versions. Meanwhile, the shape is also changed. In version 1 to 4 , it is a low square podium, but in version 5 , the podium becomes pyramidal.

The orientation is only mentioned in version 5 , where it says that the "monument has an east-west orientation, with the entrance facing the west, allowing the sun to penetrate through the end opening into the hall during the morning and evening 
hours." However, the details of the site weren't mentioned in any of the versions.

Approach: This section offers an appropriate way to observe Selene and every version has similar content. Taking version 1 as an example, Wang says, "from the distance, Selene appears as two giant arms; from the side, it appears to be one single stele. From a three-quarter view, it becomes twain. Seen from the front, the duality expresses its symbolism" He emphasized that the shape would be determined by the viewpoint and that the "dual" form showed the symbolic meaning of Selene. Wang consciously used "two," "twain," and "dual," which can have both similar and different meanings. In addition, he pointed out that, "in the full moon night, the moon will appear in between two stelae's apex". The content refers to the relationship of the moon and the Selene.

Materials: The monument is white, but the surface material differs among versions. In version 1,2 , and 3 , it is a white concrete stele. In version 4 , Wang calls for white vitreous mosaic on both the inside and outside of the monument. In version 5 , the monument is covered externally with white marble slabs and internally with white vitreous mosaic. The changes were also made to the structure. Version 1 and 2 called for concrete constructions, but Wang changed this to a steel framework in later versions.

As for the podium, it is described as concrete in every version. Its surface is paved with grey stone slabs in version 1 and 2. Wang added pavement on the podium from version 3 . According to his description, alternate stripes of dark and light grey stone are used in version 3 and 4 , but a single material with a flowing striped pattern is found in version 5. However, he didn't mention any further information about the pattern. The floor of the hall and the stair leading to it are paved with black, polished stone. In addition, a ramp is found only in version 5, which is paved with grey stone slabs like the podium. Also, there are three more subjects, Subsidiary buildings, Safety measures and Electrical installations, mentioned only in version 5 .
Examination of the program content show that the Concept, Design, and Material sections were revised (table 2). In the Concept section, there is a focus from the first version on the creation of dual representations, such as the sun and moon, the vertical and the horizontal space in the hall, and the black and white color. Wang also mentions that the contrast of interior space represents the contrast of humanity and space. Additionally, the reliefs on the walls present female and male characters. Hence, it may be appropriate to say that the intention of creating dual representations created the basic theme of the Selene project's design.

Regarding Design and Materials, Wang began to describe the hall as a chapel-like space in version 3 and later versions. Furthermore, he described the space as mystic and religious in version 4 and 5. The changing of Wang's description is not only about the image of space, but is also reflected in the Materials. The monument's structure was changed from concrete to steel framework in version 3 and later versions. This change also relates to the changes of monument's surfaces in version 4 and 5 . Furthermore the metal screen in version 4 and 5 is connected to the description of a chapel-like space.

In a letter dated May 1974, Wang mentioned the addition of the metal screen. In the program, the first appearance of the screen is in version 4 . Hence, we can deduce that version 4 was made around that period of time. In the same letter, Wang also mentions that Selene would be promoted as a national gift and it should be the reason why the committee was established. Therefore, it is highly possible that version 4 was the program he proposed to the committee when it was first established.

\section{The development of Selene's design}

This chapter will clarify the details of the revision by examining drawings of the Selene monument. In the end of this chapter, the results of the examination will be compared with the results of previous chapters in order to clarify the entire process of the Selene project.

Table2 features of the program's versions

\begin{tabular}{|c|c|c|c|c|c|c|c|c|c|c|}
\hline & \multirow{2}{*}{ Concept } & \multicolumn{6}{|c|}{ Design } & \multicolumn{3}{|c|}{ Material } \\
\hline & & image & block & relief & screen & podium shape & orientation & monument surface & structure & pavement \\
\hline Ver.1 & $\begin{array}{l}\text { dual representation } \\
\text { arm }\end{array}$ & $x$ & $\bigcirc$ & 0 & $x$ & square & $x$ & white concrete & concrete & $x$ \\
\hline Ver.2 & arm & $x$ & O & 0 & $x$ & square & $x$ & white concrete & concrete & $x$ \\
\hline Ver.4 & arm & $\begin{array}{l}\text { chapel-like / mystic, } \\
\text { religious }\end{array}$ & O & O & ○ & square & $x$ & white mosaic & $\begin{array}{c}\text { steel } \\
\text { framework }\end{array}$ & $\begin{array}{l}\text { alternate } \\
\text { stripes }\end{array}$ \\
\hline Ver.5 & arm & $\begin{array}{l}\text { chapel-like / mystic, } \\
\text { religious }\end{array}$ & ○ & ○ & ○ & pyramidal & west & white marble & $\begin{array}{c}\text { steel } \\
\text { framework }\end{array}$ & $\begin{array}{l}\text { flowing } \\
\text { stripes }\end{array}$ \\
\hline
\end{tabular}

Table3 drawings of the Selene project

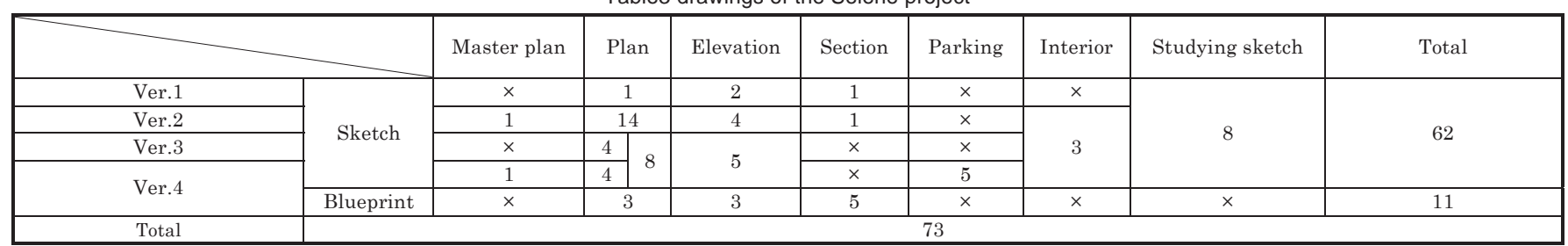




\subsection{Selene's drawings in publications}

Drawings for the Selene monument appeared only two times in architectural magazines. As mentioned previously, the first time was in Far East Builder ${ }^{41)}$ in 1970, where a plan was shown. The plan shows that the hall of Selene has a circular shape and the approach to the hall is made by a pair of symmetrical stairways. In the second publication in Taiwan Architect ${ }^{42)}$ in 1988 , the basement plan shows that instead of the symmetrical stairs a single stairway is used (table 5). Also, in this edition only, a podium with a ramp can be found. Because authors can't find any other new drawings after 1988, it can be considered as the last proposal of the Selene project.

\subsection{The development of Selene's design}

There are 73 drawings in the museum's collection, which can be categorized as blueprints and sketches. The details of the drawings can be seen in table 3 . The blueprints consist of a complete set of drawings that is dated Dec.1974. The drawings are the same as the ones seen in Taiwan Architect. Most of the sketches reviewed are without scale and date; only three plans were dated August $1974^{43)}$ and one elevation drawing was dated December $1974^{44)}$. These dated drawings are different from the drawings in PA and Far East Builder, and also differ from those of Dec. 1974. In addition, several plans different to the ones before are found. Hence, at least four versions are found in the collection, which are shown in table 5 .

Version 1's plan uses a pair of symmetrical stairs to reach the hall, which is traversable. Version 1 has a square podium and the area is $90 \mathrm{ft}^{2}$. Inside the hall, a memorial block is set in the center. Version 2 also uses symmetrical stairways, but one of them is used for approaching the basement, which makes it impossible for people to walk through the hall. Inside the hall, the block again stands in the center, but there is also a screen opposite the entrance. Version 2 has a $140 \mathrm{ft}^{2}$ square podium and a $30 \mathrm{ft}$. wide stairway to approach the podium, which also means that the podium has been made taller. Version 3 and Version 4 have the same plan of the monument with only a single stairway reaching the hall. Inside the hall, the block and the screen are found ${ }^{45)}$. Both of them have a podium that has $140 \mathrm{ft}^{2}$ surface area and pyramidal edges. A stairway is combined into the podium in version 3 while a ramp is added in front of the podium in version 4 .

In addition, three different patterns of pavement are found. The pavement of version 1 can't be confirmed, while version 2 uses pattern 1 or 2 , and pattern 3 is used in version 3 and 4 . Furthermore, the average length-width ratio of the monument is also different. In version 1 and 2 , the ratio is $1: 1.35$, but in version 3 and 4 , it becomes 1:1.5. Although the proportion changed, the size of the hall and the stairs remain the same. Hence, the difference might only serve to add a visual effect to the monument. The features of each plan can be seen in table 4 .

As for the elevations (table 5), they show the height of the podium changes from $1.3 \mathrm{ft}$. in version 1 to $3.3 \mathrm{ft}$. in version 2 , and to $3.5 \mathrm{ft}$. in versions 3 and 4 . Also, the monument's outline changes between versions. Comparing version 1 with other versions, the curved line at the lower part extends upward. This clearly alters the visual proportion of the monument, from which we infer that Wang might have tried to make the monument look more like arms rather than human hands. However, the revision of monument's outline is not just visual. Referencing the diagram of floors and outline ${ }^{46)}$, it shows the curved outline of Selene relates to its interior void space. We can see when the floor plans change from semicircular to square, causing the outline to change from curved to straight. Also, the space between two stelae changes from circular to square. We can imagine that it is a cone-like void between two stelae, which also means the void is changed gradually from cone-like to square. In other words, the longer the curved outline extends, the taller the cone-like space becomes. Hence, as the NS-section diagram shows, the cone-like space increases in height from $180 \mathrm{ft}$. in version 1 to $210 \mathrm{ft}$. in version 2 , and to $240 \mathrm{ft}$. in versions 3 and 4 . These changes create a different sensation of the space. In addition, EW-section diagram shows the relationship of the approach and the monument. As mentioned previously, to reach the hall a single stairway is used from version 2 .

There are two master plans, which are related to versions 2 and 4. Version 4's master plan shows that the project consists of three areas: the monument, the inscription wall, and the subsidiary buildings area. Two different paths link these areas. A similar plan is found in version 2, although the two differ in that in version 4 the path in front of the monument is made longer; the one in version 4 reaches almost 500ft.

Based on this examination, the focus of the revisions is on the way of accessing the monument. Instead of two access paths, Wang decided to keep only one. He added a screen in the hall and also thought of adding a stair or a ramp for approaching the podium. As for the elevations and sections, it seems that he focused mainly on the outline of the monument, which also relates to the inner cone-like space. The examination of the project shows that the tall cone-like space increases in height from the early version to the final one. It can be said that the

Table4 features of the drawing's versions

\begin{tabular}{|c|c|c|c|c|c|c|c|c|}
\hline & \multirow{2}{*}{ Date } & \multicolumn{4}{|c|}{ Monument } & \multicolumn{2}{|c|}{ Podium } \\
\cline { 3 - 9 } & & approach to hall & block and relief & screen & w $: 1$ & form & approach & pavement \\
\hline Ver.1 & $\times$ & two direction, walk through & $\bigcirc$ & $\times$ & $1: 1.35$ & square & $\times$ \\
\hline Ver.2 & Aug.1974 & one direction & $\bigcirc$ & $\bigcirc$ & $1: 1.35$ & square & stair & pattern1,2 \\
\hline Ver.3 & $\times$ & one direction & $\bigcirc$ & $\bigcirc$ & $1: 1.5$ & pyramidal & stair & pattern3 \\
\hline Ver.4 & Dec.1974 & one direction & $\bigcirc$ & $\bigcirc$ & $1: 1.5$ & pyramidal & ramp & pattern3 \\
\hline
\end{tabular}


revision of version 1 to version 2 is obvious and that later revisions follow the changes made after version 2 .

\subsection{Summary and findings}

It is evident that Wang, by revising the approach repeatedly, wanted to create one and only "path" to approach Selene, which would make people enter the hall from its west side. In addition, as we see in version 4, a $500 \mathrm{ft}$. path and the ramp serve to enhance this effect. From these revisions, it is understood that Wang put emphasis on the frontality of the monument. For the interior, the inner space becomes independent by adding the screen. Also, by revising the outline of the monument the cone-like space extends vertically, creating a dark and profound space. The focus suggests that Wang gave special significance to the main hall that made it the "center" of the whole project. As mentioned above, the revision started from version 2, which was dated August 1974.

Referencing the results of chapter 3 , version 4 of the program correlates with version 2 of the drawings, while version 5 of the program correlates to the version 4 of the drawings. On the other hand, version 1 to 3 of the program may all relate to version 1 of the drawings. Hence, the first appearance of a chapel-like space can be considered as version 2 of the drawings, and Wang revised the design in later versions with concern for this feature. In other words, to create a mystic and religious space, Wang attempted to design the only path and emphasized the hall as the center of the project consciously. At the same time, he also changed the surface materials from concrete to marble and made the monument face west. According to the date of drawings, these revisions were made in a short period of time between August and December 1974.

Combining the content of the final version of the program and drawings, Wang designed the structure so that visitors would move forward to a white marble monument in the direction of sunrise. Led by flowing linear pavement, visitors would climb up to a pyramidal podium by way of a stone ramp. In front of the visitors would be a single black stairway between two tall white walls, which would lead them to the main hall. The hall would form a dark, cone-like space with a black stone floor

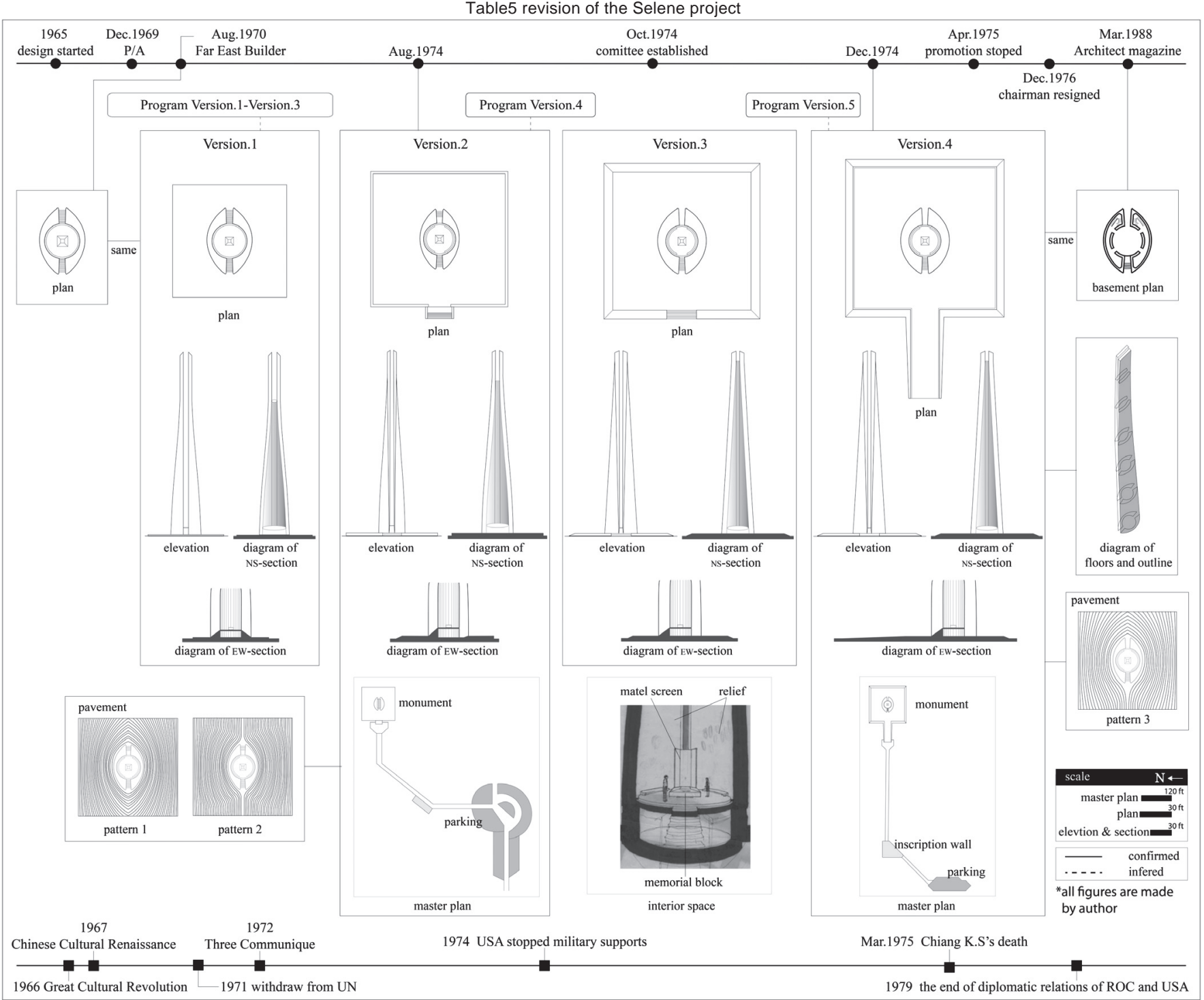


but surrounded by white glass mosaic walls. In the very center of the hall, there would stand a concrete block to commemorate the first lunar landing, while both sides of the halls would display reliefs depicting the Chinese myth of Chang-O. In the opposite side of the entrance, a screen with images of The Creation would be imbued with sunlight. We can say that what Wang presents with this design is the religious space he intended to create.

Referencing chapter 2, it may be said that version 1 of drawing is the one that Wang promoted from 1969 to 1973. Before the committee was established in October 1974, he started to revise the plans of his own volition and version 2 of the drawing is likely the one he presented to the committee and also the one he sent to America for promotion. During the period of the committee's first meeting, Wang revised the design two more times, which we see in drawing versions 3 and 4 . Version 4 became the final proposal of the Selene project, which was dated December 1974 .

Since the middle of 1974 , the revisions of the design focused on creating a mystic and religious atmosphere. It seems like the religious nature of the monument became the primary intention of the project. It is totally different from the original concept, the lunar landing that Wang presented to the public. It is interesting that he started to shift his concern in August 1974, only two months before the establishment of the committee. In other words, Wang shifted his concern in the most advanced stage of Selene's promotion.

\section{Discussion}

\subsection{The intention of the Selene project}

The shift of Wang's concern is found in previous chapters. For clarifying his real intention, it is necessary to consider the background once again.

The Selene project was designed and promoted in an unstable period in Taiwan. In the 1960s, ideological conflict raged between the KMT and CPC. The Great Cultural Revolution was a cultural movement to consolidate Mao Zedong's (毛沢東) authority and Communist ideology by advocating revolt against all perceived opposing individuals and ideologies. The revolution attempted to break the Four Olds ${ }^{47)}$ and disparaged Confucianism along with Chinese culture. It also decried everything about capitalism, including technologies and sciences.

To oppose the CPC, the Chinese Cultural Renaissance movement stressed that the KMT was the protector of Chinese culture and advocated Confucianism. KMT followers believed they were the heirs of Chinese tradition. For people like Wang, who were raised by the KMT, it is normal to share the same ideological ideas with the KMT and to advocate Chinese culture. Therefore we can see why Wang used the Chinese myth of Chang-O as the theme of his relief, even though it is little known by people in the United States ${ }^{48)}$.
In the Cold War era, American culture was imported into Taiwan together with the USAID program, ${ }^{49)}$ and it soon became synonymous with modern culture. American science and technology were at their peak, and we can say that the lunar landing was a milestone of that era. People in Taiwan also shared the same excitement leading up to and following the lunar landing ${ }^{50)}$. Wang had been educated in the western world and he was interested in cosmology and science fiction ${ }^{51)}$. It is also natural for him to admire American culture at that time. Therefore the selection of the lunar landing as his subject of design is also understandable.

However, regarding the international situation, his intention might have been more political. In July 1965, the same year that Wang said that he began the Selene project, the US stopped financial aid to Taiwan. After president Nixon visited China and declared the Three Communiqué in 1972 ${ }^{52}$, the international position of Taiwan and China was reversed. In addition, the decision of the KMT to withdraw from the UN in 1971 made the situation even worse. These diplomatic matters must have caught Wang's attention, especially since he once worked in the Chinese embassy and had a close relationship with the minister of foreign affairs.

The first lunar landing, the milestone of American science and technology advancement, inspired Wang to design the Selene project. At the same time, the project also represented the meaning of Chinese culture. It means Wang attempted to combine the values of American material culture and the spirit of Chinese culture through his project. To commemorate the lunar landing was also an action of advertising the achievement of America. Taking into consideration this background, Wang might have considered the Selene project as a way to improve the relationship with the United States. This also might be the reason he published the project in $P A$ voluntarily in the first place $^{53)}$. However, Wang shifted his concern around the year 1974. It was the era that the USA stopped their military support, which signaled the retreat of American influence from Taiwan. It was also the period that KMT leaders began to consider that their regime should become more Taiwanized ${ }^{54)}$. In other words, the dogma of Chinese Cultural Renaissance became less effective. These might be the latent reasons for Wang to shift his concern, which he might have held from the beginning.

Wang's inspiration, the mystic and religious space he tried to create, references to Chinese myths, and appreciation for modern science and technology all went against the ideology of the Great Cultural Revolution. However, Wang also refused to redesign the Selene project in the palace style, even though he needed government support to realize the project. Furthermore, he used a Chinese myth to represent Chinese culture and at the same period of time, he mentioned in an essay that to become a real Chinese, it is necessary to read Dream of the Red Chamber 
(紅樓夢) ${ }^{55)}$, which he thought of as a novel about Buddhism. Nowhere in this are the values that Confucianism represented. Wang was also against accepting American culture overall, and he criticized the extreme development of industrialization and materialism. Rather, he highly valued spiritual life, such as art and religion. As he said, "by admiring materialism and science uncritically, we kill our spiritual life. Our arts and religions are being developed poorly. To continue on this course does not only destroy the balance of life, but also destroys life itself." ${ }^{\text {"6) }}$

Wang's true intention is revealed in an essay called "Ideas for architecture and architects," published in 1971. He took monuments as “spiritual architecture (精神的建築)" that are built to fulfill spiritual needs not for material benefit ${ }^{57)}$. He stressed repeatedly that he was only responsible for the design. He tried to keep practical matters at a distance, and the revision of the project showed that he tried to create this mystic and religious space. Wang's actions showed that he tried to put his ideas into practice.

Although Selene was a highly political and ideological project, the fact that Wang participated in political activities can't be confirmed. It can even be said that Wang tried to keep his distance from those things. Therefore, we may say that he advocated the autonomy of architecture, because his intentions showed that he distanced himself from the Great Cultural Revolution, the Chinese Cultural Renaissance, and also American material culture.

\subsection{The Chineseness of the Selene project}

Wang's idea of "dual representation" inspired him to create the form of Selene. He consciously used "twain" and "dual" to describe the two stelae. Independent yet seemingly identical stelae stand facing each other, representing the meaning of twain. Through Selene's programs, Wang also suggested various dual representations. The sun and moon, male and female, humanity and space. These matters convey a relationship of relative existence; the vertical and horizontal space, the black and white, both convey a contrastive existence. Wang included them into the idea of Ying-Yang. However, unlike the meaning of twain, Ying-Yang means a structure of dichotomy, which represents a mutual existence of two relative matters ${ }^{58)}$. It is like the author of Dream of the Red Chamber says, "Ying-Yang, these two words are one word. ${ }^{59}$ ). Two relative things rely on each other. As a result, Wang was inspired by this idea, and designed a dark and confined space that rose vertically into the sky endlessly and due to this sense of depth Wang described it as being mystic and religious. Seeking for mysteriousness may be the essential part of Wang's Chineseness.

Based on the authors' previous study ${ }^{60)}$, Wang's idea of Chineseness relates to the experience of living in Suzhou residences. It was a space with a deepness that was formed by the repetition of bright and dark, closure and continuation. Wang thought the space was mystic and he took it as an essential feature of Chinese space. Wang stressed the same features in the Selene project. Although Wang presents the atmosphere of space more intuitively by the towering and dark space without repetition, he still shares the same idea of being mystic and regards the mutual existence of two relative matters as the key idea of his design. Therefore, we can consider that the sense of mystique as the essence of his Chineseness.

\section{Conclusion}

In chapter 2, Wang's position in the 1960s is discussed. Although he had a close relationship with the KMT government, Wang still disagrees with the government's cultural policy and it might have been the reason that triggered him to promote the Selene project. Chapter 3 clarifies the process of project's promotion. It can be seen that the promotion wasn't going as well as Wang claimed. In chapter 4 , the program of the project is examined. The focus falls on his intention of creating a dual representation. It also shows Wang changed his idea and it is understood that he was seeking a mystic and religious chapel-like space in the middle of 1974 . The drawings of the project are examined in chapter 5. Four versions of the design existed and the focus of the revision is to create a singular path and the central space of the monument, which relates to the chapel-like space that Wang mentioned. Chapter 6 discusses the intention and the meaning of the Selene project. It was a highly political and ideological project, but Wang kept a certain distance from any political and ideological discussions during the Cold War era and he stressed the autonomy of architecture by advocating its spiritual values. He also searched for the idea of Chineseness. The Selene project represents the mutual existence of relative matters and it is clear that the sense of mystique is an essential idea behind his conception of Chineseness. Furthermore, by emphasizing the autonomy of architecture, Wang also shows that the Chineseness, which he seeks for, goes beyond any ideological and political issue.

Notes

The file names of the collection are composed of 12 characters containing both letters and numbers. The files that are most used in this paper begin with the following 9 characters, NWDH12068. Hence, the authors will only show the last 3 figures of these file numbers. However, complete file numbers will be noted in case of exceptions.

1）王大閏著, 李宗哲編, 大失敗, 銀色的月球, 通俗社, 2008, p. 31. Originally published in 中華日報, 1984 .

2) File no.024, Wang Da-Hong Collection, National Taiwan Museum.

3）李乾朗，20世紀台灣建築，玉山出版，2001，p. 117.

4）徐明松，建築師王大閏：1943-1995，誠品，2010，p. 138 .

5) Chiang Ya-Chun, Architectural Discourse and Design Practice of Transplanted Modernity: Wang Dahong and the Polemics, 1950-60s, National Taiwan University, 2005, pp.92-187.

6) The first published profile of Wang was 王大閏作品集(蕭梅編, 啓源書局, 1997). Later in the 2000s, a series of books about Wang was published by 徐明松, such as 建築師王大閏 1942-1995 (誠品, 2010). The publications in 
2000s are made based on the first profile.

7) The original Chinese title is 二次戰後台灣經典建築設計圖說徵集暨研究

計劃. The English title is translated by the author.

8) More details in the official report. 吳光庭編, 國立臺灣博物館二次戰後台 灣經典建築設計圖說徵集研究計劃報告書, 國立臺灣博物館, 2011.

9) In the collection of Selene project, the written material files, maps and photos are classified from file number NWDH12068001 to NWDH12068 -168, NWDH12068170 to NWDH12068211, NWDH1203001 to NWDH12 -03004 and NWDH1204001 to NWDH1204003. The drawings are NWDH 12058169, NWDH12051003 to NWDH12051009, NWDH12021001 to NWDH12021048 and NWDH12022001 to NWDH12022011. However, NWDH12021043, NWDH12021024, NWDH12051006, NWDH12051007 have multiple drawings per sheet in the file.

10) Wang Chung-Hui (1881-1958) was a jurist and a politician who served the Republic of China from its foundation in 1912 until his death in 1958. He was a close associate of Sun Yat-sen, an active member of the KMT, and a judge on the Permanent Court of International Justice in Hague.

11) GSD stands for Harvard Graduate School of Design. Wang studied in Kings College for his bachelor degree from 1936 to 1940 and got his master degree at GSD in 1942.

12）徐明松著, 静黙的光低呤的風王大閏先生, 遠景, 2012, pp. 40-44.

13）王建柱編, 真源與妄跡, 藝術家 vol. 48, 藝術家雜誌社, p. 66.

14) Official documents are categorized as meeting records (9 sheets), press releases ( 7 sheets), name lists (4 sheets), schedules, (2 sheets) and others (14 sheets). Apart from the redundant files, there are 30 letters in the collection.

15) Progressive Architecture, Reinhold, vol.12, 1969, p.31.

16) Far East Builder, Far East Trade Press Limited, 1970.08, pp.18-19.

17) File no.041, 042, 107, Wang Da-Hong Collection, National Taiwan Museum.

18) An international organization for cultural exchange, which has branches all over the world. The one in Taipei was founded in 1957. 19) File no.113, Wang Da-Hong Collection, National Taiwan Museum. 20) Far East Builder, Far East Trade Press Limited, 1970.08, pp.18-19. 21) The construction of buildings with more than 5 floors was forbidden. 22) File no.102, Wang Da-Hong Collection, National Taiwan Museum. 23) ibid, file no.112.

24) An organization for promoting the relationship between Taiwan and America founded in 1954 by leaders of culture and commerce. The first chairman Lian Han-Cao (梁寒操) was also the first chairman of the Selene construction committee.

25) File no.029, Wang Da-Hong Collection, National Taiwan Museum.

26) ibid, file no.057.

27) ibid, file no.121, 189 .

28) ibid, file no.053, 054.

29) They proposed a terrain near the Johnson space center, an American aeronautics and space center located in the Clear Lake Area of Houston. Wang handed the proposal to the committee and it became the official one. (File no.051, Wang Da-Hong Collection, National Taiwan Museum.) 30) ibid, file no.164, 165, 166.

31) ibid, file no.023, 024,162.

32）臺六十四秘字第三三六四號, 立法院議案關係文書, 中華民國立法院, 1975. 33) File no.103, Wang Da-Hong Collection, National Taiwan Museum.

34) ibid, file no. 118.

35) ibid, file no.045

36) The Introduction doesn't mention anything about design. In addition, programs in Chinese are also in the collection but they are the translations of English programs, especially from version 2 and 3.

37) The story was first mentioned completely in Huainanzi (淮南子, 139 BC. ). The story was about Chang-O and her husband Hoyee. Hoyee became the emperor after he saved people from the suffering of ten suns in the sky. However, he was a tyrant. One day, Hoyee got the elixir of life. Chang-O thought that if Hoyee got eternal life, people would suffer forever. Hence, she stole the elixir and drank it. Suddenly, Chang-O flew to the moon. Stealing and betraying her husband is regarded as an immoral behavior in Chinese culture. Wang planned to have the relief of
Chang-O on one side of the wall and relief of Hoyee on the other side. 38) Including fragmented pages, there are 35 sheets in this category. 39) ibid, file no.147.

40) ibid, file no. 145 .

41) Far East Builder, Far East Trade Press, 1970, pp.18,19.

42）建築師雜誌, 中華民國建築師公會, 19883 月號, pp. 97-99.

43) File no. NWDH12021033, NWDH12021035, NWDH12021040, Wang Da-Hong Collection, National Taiwan Museum.

44) ibid, file no. NWDH12022007.

45) ibid, file no.002, 004, 006, 007, 008, 009, 010, 033, 034, 036.

46) The diagram is made by authors who references to the section-plan (file no.NWDH12021015) in the collection.

47) Old customs, old culture, old habits, and old ideas.

48) Wang sent a translation to explain the story to his American friends.

File no.083, Wang Da-Hong Collection, National Taiwan Museum.

49) The US Government agency that is responsible for administering civilian foreign aid. Taiwan received almost 4 billion dollars in financial aid, as well as military aid from the US government during the period of 1945-65.

50）蔡明彥著, 燃燒的年代-70 年代台灣文學論爭史略, 台灣文學館, 2012, pp. 19-23.

51）王大閏著, 李宗哲編, 吸收世界上奇妙的色彩, 銀色的月球, 通俗社, 2008, p. 98. Originally published in 中華日報, 1978 .

52) A collection of three joint statements made by the USA and China. It played a crucial role in the normalization of relations between the two countries, and included discussion of the territorial issue of Taiwan.

53) File no.062, Wang Da-Hong Collection, National Taiwan Museum. 54）若林正丈著, 李承機など訳, 戰後台灣政治史一中華民國台灣化的歷程, 臺灣 大學出版中心, 2014, pp. 142, 163-169.

55）王大閏著, 李宗哲編, 吸收奇妙的色彩, 銀色的月球, 通俗社, 2008, p. 99. Originally published in 中華日報, 1978 .

56）王大閏著, 李宗哲編, 中國建築能不能繼續存在, 銀色的月球, 通俗社, 2008,

p. 64. Original published in 百葉窗, 1963.

57) ibid, 對建築和建築師的一些想法, p.67. Originally published in The Economic News, 1971.

58) The dichotomy in the western context shows a differentiating line between two things which are stratified. The same idea was seen in KMT's rule. KMT highlighted the particular part of Confucianism, which emphasized the dichotomic structure, especially between government and people. Generally, Confucianism emphasizes the differences between two opposing forces, such as good and evil. (梁啓超, 儒家哲學, 北京大學出版 社, 2010, pp.143-148.) In its social philosophy, it stresses a clear line between social ranks. For instance, Confucius said "The ruler should rule, the minister should minister, the father should be a father and the son should behave like a son (君君臣臣父父子子)”. However, Wang suggests a different opinion of dichotomy.

59）曹雪芹著, 井波陵一訳, 新訳紅楼夢, 第二冊, 岩波書店, 2013, pp. 299-300. 60）郭聖傑, 木村智, 田路貴浩，台湾建築家王大閏における「中國的」という 観念一中國住宅に関する言説を通して, 日本建築学会計画系論文集 $80(710)$, 2015. 04, pp. 971-979.

References of images

Fig.1）李乾朗著, 20 世紀台灣建築, 玉山社, 2006, pp. 108, 118.

Fig.2）徐明松著, 王大閏：永恆的建築詩人,木馬文化, 2007, p. 129 (National Palace Museum project). 蕭梅編, 王大閏作品集, 啓源書局, 1997, pp. 22, 59 (Sun Yet-Sen Memorial Hall, Ministry of Foreign Affairs building). 徐明松著, 建築 師王大閏 1942-1995, 誠品, 2010, p. 196 (Ministry of Education building). Fig.3) Far East Builder, Far East Trade Press Limited, 1970.08, pp.18-19. 


\section{和文要約}

\section{1 章 はじめに}

台湾建築家の王大閏は1969年に「人類登月記念碑」計画案を発表 した。それは、アメリカのアポロ11号によってはじめて成功した月 面着陸を記念するモニュメントである。1960、70年代の王は国家的 プロジェクトの設計競技に次々と勝利を収め、多数の計画を手掛け ていた。そうしたなか、この架空のプロジェクトの考案と実現に努 めた。王はこのモニュメントが「深い中華文化を意味」するもので あり、「中国的なもの」であることを強調して語っており、この計 画案を王が探求しつづけた中国性 (Chineseness) のもつとも重要な 実例と位置づけることができる。本研究は国立台湾博物館の未公開 資料を用い、この計画案の経緯と内容を明らかにし、人類登月記念 碑における中国性の内実を論じる。

\section{2 章 1960 年代における王の公共建築作品}

政府の要人である父を持つ王は、国民党政府との親密な関係を持 っていた。1947年に上海に戻ると、実作の経験がなかったにもかか わらず、政府の大上海都市計画（1945-49）の計画案に参加した。し かし、1949年の中国内戦後、王は香港、ついで台湾に移住した。政 治的には反共の立場にあった。1960年代、台湾政府は公共建築を政 治と文化政策の宣伝に利用していた。とくに1967年から10年間にわ たって推進した「中華文化復興運動」によって中国文化を顕彰して いた。この時期、王は故宮博物館計画案、孫文記念館、外交部ビル、 教育部ビルなど、重要な公共建築を設計する機会を得ていた。しか し、孫文記念館では、伝統的な様式に近付けるよう政府から原案の 大幅な修正が求められるなど、しばしば政府側から伝統的様式の強 調を要求され、それに対する異議を表明している。そうしたなか、 人類登月記念碑案が計画された。

\section{3 章 人類登月記念碑計画の推進活動}

国立台湾博物館が所蔵する公文書および書簡の分析を通して、計 画案の推進経緯を把握する。1971年から王は個人的に推進活動を始 めた。1974年の前半、当時の外交部長の助言により、人類登月記念 碑をアメリカ独立 200 周年の記念として贈ることになった。これをき っかけに、「中華民国国民籌建登月記念碑委員会」が1974年10月に 発足し、計画案の実現を本格的に推進することになった。1975年3 月、立法院のある議員が推進活動は民間ではなく政府主導でを行う べきであると主張し、王の計画案について「中國文化を代表してい ない」と批判した。これに対して王は、人類登月記念碑は「陰陽哲 学」をあらわしていると主張した。1975年に蒋介石が死去すると、 計画は一時中止され、次いで、78年の台米断交によって推進活動は 中断した。やがて寄付の不足、政府の支援の途絶によって、推進活 動は停止してしまった。1980年になると王は個人的に活動を再開し、 それは90年代まで続いた。しかし、最終的に計画案は実現しなかっ た。

\section{4 章 人類登月記念碑計画のプログラム}

本章では計画プログラムに着目する。国立台湾博物館所蔵のプロ グラム草稿には、 5 つのバージョンが存在している。最初のバージ ヨンで、王は「二元的な表現」を設計の基本コンセプトとし、モニ ユメントの形を手を月に伸ばすイメージとした。 5 つのバージョン
のなかで、バージョン 2 と 3 の間の変更が著しい。変更されたのは、 モニュメントの表面の素材、基壇の形などである。また、バージョ ン 3 以降、内部を「教会のような」空間と性格づけ、バージョン 4 以降では、ホール内に金属屏風を追加し、内部の「神秘的」「宗教 的」性格を強めている。1974年5月の書簡には、金属屏風の新設に触 れられていることから、バージョン 4 はこれ以前に作成されたと言 える。また、同じ書簡には、人類登月記念碑を国家的な寄贈にしよ うという考えも記されている。したがって、同年10月に委員会が成 立された際、王はバージョン 4 を提出したと考えられる。

\section{5 章 記念碑設計の過程}

全図面を分析した結果、設計プロセスを 4 つのバージョンに区分 することができる。バージョン 1 から 2 の間に大きな設計変更が認 められる。バージョン 2 で、王はモニュメントに到達する唯一のア プローチを計画し、モニュメントの正面性を強調している。また、 モニュメントの輪郭線の修正が重衫られ、人間の手のひらから腕の 形に近づけられている。それによって、内部空間は上方へ広がり、 より奥深い空間になっている。金属犀風が設置されるなど、修正は ホールに集中しており、ホールを計画案の中心とする意図が感じら れる。また、バージョン 2 はプログラムで説明された神秘的、宗教 的空間に対応寸るものと考えられる。プログラムの内容と合わせる と、最終案では、太陽の方向に向かって、石柱のようなモニュメン 卜に進み、基壇を登ることになる。さらに白い壁の間にある黒い階 段を登り、黒い床のホールへ入る。ホールは白い空間であり、ホー ルへ入ると、太陽の光に照らされた屏風が目の前に現れることにな る。この一連の移動はきわめて儀式的であり「宗教的」といえる。 計画案の修正は1974年の委員会設立前後に集中している。この時期 に、王が科学技術礼讃から、神秘的、宗教的空間の創造へと設計意 図を変化させたことに注目される。

\section{6 章 考察}

人類登月記念碑が提案された時代は文化冷戦時代であり、国際情 勢の転換期でもあった。この計画案は、こうした時代状況のさなか、 アメリカの物質的な科学技術と中国の伝統文化の精神を融合させよ うとするものであった。そこには台米関係の修復の意図もうかがえ る。王は中国の伝統文化の擁護が、中国共産党による文化大革命の 対抗となることを知っていたはずである。人類登月記念碑はきわめ て政治的、イデオロギー的状況の中で構想されたが、王が政治的な 問題に積極的に関与した事実は確認できない。むしろ、王はこのモ ニュメントを「精神的建築」と称し、人類登月記念碑を建設するこ とによって、建築の精神性を喚起しようとしている。王は文化大革 命とも、その対抗運動である中華文化復興運動とも、アメリカ物質 文明とも距離を取ろうとしたのであった。王は人類登月記念碑が示 す建築の精神性（芸術性、宗教性）を強調することで、いっさいの 政治的イデオロギーから距離を取り、建築の自律性を主張したので ある。他方、王は「二元的な表現」というコンセプトを提起し、相 対的なことの共存を強調する。それは「陰陽」とも捉えられていた。 計画案では、暗く狭い、はるか上方へと立ち上る奥深い内部空間が 構想され、その特質は「宗教的」で「神秘的」なものと捉えられて いる。これらは王が幼少期に体験した蘇州住宅の特質に一致してお り、これこそ王が探求し続けた中国性といえるだろう。

（2015 年 12 月 24 日原稿受理， 2016 年 6 月 6 日採用決定） 